\title{
REORIENTASI GERAKAN FEMINISME ISLAM; Sebuah Upaya Membangun Kesetaraan Perempuan
}

\author{
ABD. WARITS \\ (Institut Ilmu Keislaman Annuqayah Sumenep) \\ Email: aries.ilham28@gmail.com
}

\begin{abstract}
In the history of women's life, the woman has never cracked from the wild cry of helplessness. Woman always become victim of men's egoism, marginalized, hurt, unfettered, fooled and never appreciated the presence and role. This situation troubles many intellectual Muslims who have perspective that Islam teaches equality, equality for all human beings in the world. The difference in skin color, race, tribe and nation, as well as gender does not cause them to get the status of the different rights and obligations. The potential and the right to life of every human being and the obligation to serve the Lord Almighty is the same. Indeed, all human beings, as caliph in the world, have the same obligation, namely to prosperity of life in the world. No one is allowed to act arbitrarily, destroying, or hurt among others. They are required to live side by side, united, and harmonious, help each other and respect each other. However, that "demand" never becomes a reality. The differences among human identities become a barrier and the cause of divisions. For them, those who are outside environment, different identities are "others" who rightly do not need them "know". The difference of identity has become a reason to allow "hurt" each other. Several intellectual Muslims who recognize the wrong (discrimination against women), and then they attempt to formulate a movement for women's liberation. All the efforts have been done on the basis of awareness that arbitrary action by any person can never be justified. They also realize, that the backwardness of women are "stumbling block" that will lead to the resignation of a civilization. However, this struggle found a lot of challenges; including the consideration of "insubordination" to conquer the power of men, despite it had done by using many strategies. Starting from the writing of scientific book and countless fiction themed women has been published in order to give awareness of equality between men and women. This paper seeks to reexamine the process of the empowerment struggle to give a brand new concept, so that the struggle of women empowerment is not as insubordination and curiosity process in an attempt to conquer the male. Through approach of literature review and observations on the relationship between men and women, the writer finally concluded that the movement of Islamic feminism is not a movement to seize the power of men, but an attempt to liberate women from oppression so that they get the rights of their social role, giving freedom for women to pursue a career as wide as possible like a man, without forgetting a main duty as a mother: to conceive, give birth and breastfeed their children.
\end{abstract}




\begin{abstract}
Abstrak
Sepanjang sejarah kehidupan perempuan, tidak pernah lekang dari jerit tangis ketidakberdayaan. Mereka selalu menjadi korban keegoisan laki-laki, termarginalkan, tersakiti, terkekang, didzalimi, dibodohi dan tidak pernah dihargai keberadaan dan peranannya. Situasi ini meresahkan banyak intlektual muslim yang melihat bahwa agama Islam mengajarkan kesetaraan, kesejajaran bagi seluruh manusia. Perbedaan warna kulit, ras, suku dan bangsa, juga perbedaan jenis kelamin tidak menyebabkan mereka mendapatkan status dengan hak dan kewajiban berbeda. Potensi dan Hak hidup setiap manusia serta kewajiban untuk berbakti pada Tuhan SWT. tetap sama. Sejatinya, seluruh umat manusia, setelah didaulat sebagai khalifah di bumi oleh Tuhan, memiliki kewajiban yang sama, yaitu memakmurkan kehidupan di bumi. Tidak ada satupun yang diperbolehkan bertindak sewenang-wenang, melakukan pengrusakan, ataupun menyakiti diantara sesama. Mereka dituntut hidup berdampingan, bersatu, rukun, saling membantu dan saling menghormati satu sama lain. Namun demikian, "tuntutan" tersebut tidak pernah menjadi kenyataan. Perbedaan identitas diantara manusia menjadi penghalang dan penyebab perpecahan. Bagi mereka, orang yang berada di luar lingkungannya, berbeda identitas adalah "orang lain" yang sepantasnya tidak perlu mereka "kenal". Perbedaan identitas tersebut telah menjadi satu alasan diperbolehkanya "menyakiti" satu sama lainnya. Kalangan intlektual muslim yang menyadari kekeliruan (diskriminasi bagi perempuan) tersebut, kemudian berupaya merumuskan satu gerakan pembebasan bagi perempuan. Kesemua upaya tersebut dilakukan karena adanya kesadaran bahwa tindakan sewenang-wenang oleh siapapun tidak pernah bisa dibenarkan. Mereka juga menyadari, bahwa keterbelakangan perempuan adalah "sandungan" yang akan menyebabkan mundurnya sebuah peradaban. Namun, perjuangan ini menemukan banyak tantangan; termasuk dianggap "pembangkangan" untuk menaklukkan kekuatan lakilaki, meski telah dilakukan dengan berbagai strategi. Mulai dari penulisan buku ilmiah, hingga fiksi bertema perempuan sudah tak terhitung jumlahnya yang dipublikasikan demi memberikan kesadaran akan adanya kesetaraan antara laki-laki dan perempuan. Tulisan ini berupaya menelaah ulang proses perjuangan pemberdayaan tersebut guna memberikan tawaran konsep baru, sehingga perjuangan pemberdayaan perempuan tidak lagi dipandang sebagai proses pembangkangan dan dicuriagai sebagai upaya menaklukkan laki-laki. Melalui pendekatan kajian kepustakaan dan pengamatan terhadap relasi antara laki-laki dan perempuan, akhirnya penulis berkesimpulan bahwa gerakan Feminisme Islam bukanlah gerakan untuk merebut kekuasaan laki-laki, melainkan sebuah upaya untuk membebaskan kaum perempuan dari ketertindasan sehingga mereka mendapatkan hak-hak peran sosialnya, memberikan keleluasaan bagi perempuan untuk berkarir seluas-luasnya layaknya laki-
\end{abstract}


laki, namun tetap tidak melupakan tugas kodratinya sebagai seorang ibu: untuk mengandung, melahirkan dan juga menyusui anak-anaknya.

\author{
Kata Kunci: Reorientasi, Gerakan Feminisme, Islam
}

\title{
Pendahuluan
}

Perbincangan kehidupan perempuan tidak pernah lekang dari zaman. Sejak Adam sampai Muhammad, dari zaman Muhammad hingga sekarang, persoalan perempuan dengan berbagai sisi kehidupannya tetap aktual diperbincangkan. ${ }^{1}$ Dalam sejarahnya, perempuan selalu menjadi objek tindakan diskriminiasi. Ini ditimbulkan oleh sistem patriarkhi yang mengakar kuat dalam tatanan kehidupan manusia, hingga doktrin agama sulit terlepas dari pengaruh budaya patriarkhi. ${ }^{2}$ Akibatnya, perempuan dipandang sebelah mata oleh laki-laki.

Gerakan permberdayaan perempuan, atau seringkali dikenal dengan istilah Feminisme, ${ }^{3}$ merupakan satu gerakan yang muncul sebagai respon atas prilaku diskriminasi tersebut. Gerakan ini berupaya mengembalikan posisi perempuan sebagai makhluk berdaya, hidup bebas; bebas dengan konsekwensi tentunya, tanpa diskriminasi dan penindasan melalui pendidikan, penyadaran, dan pembelaan pada hak-hak perempuan. yang selama ini telah dirampas secara "diam-diam" oleh kaum laki-laki. ${ }^{4}$

1 Dikutip dari wawancara Ahda Imran dengan Abidah el-Khalieqy dalam Harian Pikiran Rakyat Bandung, edisi tidak terlacak.

2 Abd. Warits, Menggugat Tafsir Patriakhi; Upaya Membebaskan Kaum Perempuan, dalam Dr. Jainal Aripin, MA., (Ed.), Kajian Islam Multidisipliner (Jilid 3), (Jakarta: UIN Syarif Hidayatullah Press, Mei 2010), 3.

3 Sebelum membahas jauh tentang Feminisme, terlebih dahulu harus kita sepakati pemahaman istilah Gender dan Seks serta relasi keduanya dalam gerakan Feminisme. Kata "seks" disini jangan kita pahami sebagai hubungan badan antara suami dan istri, tetapi seks tersebut dimaksudkan sebagai suatu perbedaan antara laki-laki dan perempuan yang ditentukan secara kodrati (Natur), perbedaan yang tidak bisa dipertukarkan karena sudah merupakan ketentuan dari Tuhan bagi laki-laki dan perempuan. Perbedaan seks bisa dilihat pada organ jenis kelamin keduanya yang berbeda (Penis bagi laki-laki dan vagina bagi perempuan), menstruasi, mengandung, dan melahirkan pada perempuan, sementara laki-laki tidak bisa melakukan hal itu. Sedangkan Gender, adalah relasi antara laki-laki dan perempuan yang ditentukan berdasarkan kondisi lingkungan sosial-budaya (kultur). Oleh sebab itu relasi gender bisa dipertukarkan, sebab gender bersifat relatif, fleksibel sesuai dengan kebutuhan sosial yang ada. Sedangkan Feminisme, adalah gerakan yang berusaha mewujudkan keseteraan gender antara perempuan dan laki-laki di masyarakat. Lihat pada skripsi Muhammad Suhaidi RB, Dekontruksi Tafsir..., 82-96.

4 Periksa, Moh. Raqib, Pendidikan Perempuan, (Yogyakarta: Gema Media, 2003), 21. Banyak kalangan menyampaikan pandangan berbeda tentang pengertian feminisme. Seperti yang dideskripsikan oleh Mansour Fakih, sebagimana dikutip Abdul Mustaqim, bahwa "Feminisme merupakan satu pemberontakan kaum perempuan untuk mengingkari kodrad atau fitrah perempuan, melawan pranata sosial yang ada, atau isntitusi sebuah rumah tangga, seperti perkawinan dan lain sebagainya". Periksa Abdul Mustaqim MA., Tafsir Feminis Versus Tafsir Patriarkhi: Telaah Kritis Penafsiran Dekontruktif Riffat Hasan, (Yogyakarta: LKiS, 2002), 15. Sementara, Ali Husain al-Hakim menulis, "Feminisme lahir karena adanya tatanan yang tidak adil dan menyedihkan, yang harus ditanggung perempuan sepanjang sejarah. Hal itu sebagai bentuk kesadaran bahwa perempuan telah ditindas dan tidak diuntungkan jika dibandingkan dengan pria. Sementara penindasan tersebut tidak sepantasnya dilakukan, dan tidak dibenarkan oleh prinssip keadilan. Periksa Ali Husain al-Hakim, Status dan Komplementaris Dua Gender, 
Tujuan gerakan Feminisme adalah meningkatkan kedudukan dan derajat perempuan agar setara dengan laki-laki, sekaligus membangun kemandirian bagi perempuan. Perjuangan serta usaha kaum feminis untuk mencapai tujuan ini mencakup berbagai cara. Salah satunya adalah memberikan "porsi" atau takaran hak dan peluang yang sama bagi perempuan dengan laki-laki dalam menjalani aktivitasnya terutama dalam aspek pendidikan dan aktivitas sosial lainnya. ${ }^{5}$

Istilah Feminisme; meski terdapat beberapa perdebatan, muncul sebagai kelanjutan dari gerakan perempuan yang muncul pertama kali di Inggris pada tahun 1890.6 Gerakan ini bersifat politis, dengan fokus gerakan memperjuangkan hak suara perempuan dalam pemilihan umum (Pemilu Inggris). Lalu, pada perkembangannya gerakan perempuan tersebut berimbas pada hal lain, seperti persoalan ekonomi, sosial, hingga persoalan teologis.

Pada perekembangan selanjutnya, Feminisme berkembang menjadi beberapa aliran berbeda diantaranya: Feminisme Liberal, Marxis, Radikal, dan Feminisme Sosialis. Keempat aliran tersebut lahir dan berkembang di Barat, dengan tipe gerakan yang "sederhananya" menuntut kesetaraan, persamaan perempuan dengan laki-laki secara total, penyetaraan dalam semua hal. Karena itu, di kalangan masyarakat Eropa lalu bermunculan perempuan yang tidak mau menyusui, dan mengasuh anaknya. Bahkan, mereka juga tidak mau mengandung (hamil), karena pekerjaan itu hanya akan menyulitkan karir sosialnya. ${ }^{7}$

Gerakan Feminisme begitu cepat menjalar ke seluruh dunia, tidak terkecuali dunia Islam. Ketika berkembang ditengah kalangan muslim, Feminisme barat, mendapatkan sorotan, kecaman bahkan penolakan. ${ }^{8}$ Namun, setelah melalui perdebatan panjang, dan telaah kritis atas ajaran Feminisme barat, kemudian lahirlah konsep Feminisme Islam sebagai respon atas pesatnya perkembangan Feminisme di peradaban barat.

Lahirnya konsep Feminisme Islam tiada lain karena mereka (pegiat feminis islam) melihat adanya beberapa kekeliruan dalam konsep Feminisme Barat, yaitu:

dalam Ali Husein Hakiem dkk., Membela Perempuan Menakar Feminisme dengan Nalar Agama, (Jakarta; Al-Huda, 2005), 59. Sebenarnya, selain ungkapan kedua tokoh tersebut, masih banyak pandangan pemikiran berbeda, tentang pengertian dan awal lahirnya feminisme, hal ini disebabkan perbedaan latar belakang munculnya gerakan feminisme diberbagai daerah tersebut.

5 Putri Diah Ningrum, "Ketidakadilan Jender Dalam Novel Perempuan Berkalung Sorban Karya Abidah El Khalieqy : Tinjauan Sastra Feminis," Skripsi, tidak diterbitkan, (Surakarta: FKIP Bahasa dan Sastra Indonesia, UNMUH, 2009), 17.

6 Versi berbeda menyebutkan bahwa istilah feminisme pertama kali ditemukan dalam teks kedokteran Prancis, untuk menjelaskan tentang akhir perkembangan organ seksual dan karateristik kesabaran pria. Pada perekembangan selanjutnya, istilah femenisme digunakan ketika perempuan mencoba mempertanyakan dan menuntuk posisi sosialnya agar disedarajatkan dengan laki-laki. Periksa, Said Reza Ameli, Harapan-Harapan Feminis dan Respon Perempuan Muslim, dalam Ali Husien Hakim, Membela Perempuan..., 27.

7 Lihat lebih jauh pada, Husnul Khatimah, Arus Balik Feminisme (Online), dalam http://www.scribd.com/doc/27568545/arus-balik-feminisme. tanggal 18 September 2010.

8 Penolakan tersebut diawali munculnya asumsi, bahwa seluruh gerakan yang diprakarsai kalangan Barat memiliki agenda global untuk mengukuhkkan hegemoninya bagi negara islam, Periksa, M. Shiddiq al-Jawi, Menghancurkan Agenda Barat : Feminisme Politik Barat, dalam http;/ / www.swara.muslim.net. 
tuntutan penyamaan secara total dengan laki-laki, yang kemudian menyebabkan lahirnya berbagai macam masasalah, seperti: banyaknya perempuan yang enggan hamil, melahirkan, dan menyusui anaknya, mereka juga enggan menyelesaikan pekerjaan rumah tangga yang dianggapnya sebagai simbol penjajahan laki-laki. ${ }^{9}$

Konsep Feminisme Islam menolak hal itu, mereka fokus memperjuangkan hak-hak perempuan di ranah sosial. Menuntut adanya kesempatan yang sama dalam mengaktualisasikan segenap potesi disegala bidang, mulai dari pendidikan, ekonomi, sosial, hingga politik. Namun, juga tidak memberikan kecaman bagi perempuan yang hanya sibuk dengan urusan rumah tangga. ${ }^{10}$

Bagi mereka, Tuhan telah menyatakan dengan jelas bahwa antara laki-laki dan perempuan memang terdapat perbedaan fungsi fisiologis masing-masing organ keduanya, yaitu perempuan mengalami menstruasi, hamil, melahirkan dan menyusui, sementara laki-laki tidak. Hal tersebut diakuinya sebagai kodrat yang tidak boleh ditolak. Namun hal tersebut, tetap tidak bisa dijadikan alasan untuk mendiskreditkan peran perempuan.

Kajian ini berupaya menelaah konsep dan alur gerakan Feminisme Islam untuk kemudian berupaya merumuskan strategi pendidikan pemberdayaan perempuan yang pas sehingga dapat memberikan "kesejajaran" bagi kaum perempuan tanpa mereka harus meng(di)klaim sebagai pemberontak. Satu konsep pendidikan yang diharapkan bisa memberikan kemandirian, kekayaan kreativitas, namun tetap bisa membuat perempuan mampu menjalani kehidupan kodratnya; mengandung, dan melahirkan anak cucu Adam.

Dari kajian ini diharapkan bisa memunculkan satu pemahaman bahwa pemberdayaan perempuan tidak akan membuat mereka liar dan tidak terkendali, sebagaimana dikawatirkan banyak orang. Namun justru akan mampu melahirkan generasi yang hebat, sebab ibu (perempuan) yang berpendidikan dan berwawasan luas akan mampu memberikan pendidikan dasar yang mumpuni bagi anak-anaknya. Inilah yang kita inginkan, memberikan kesempatan yang luas bagi perempuan ketika akan mengaktualisasikan segenap potensi dirinya.

\section{Karakteristik Gerakan Feminisme Islam}

Islam datang sebagai agama untuk memperbaiki tatanan moral manusia, memberikan sesuatu yang terbaik bagi seluruh kehidupan manusia, salah satunya adalah mewujudkan masyarakat tanpa penindasan, hegemoni dan bebas dari prilaku diskriminasi diantara sesama. ${ }^{11}$

\footnotetext{
9 Abd. Warits, Nilai-Nilai Pendidikan Pemberdayaan Perempuan dalam Gerakan Feminis Islam, (Sumenep; STIKA Press, 2009), 34.

10 Abd. Warits, Nilai-Nilai Pendidikan Pemberdayaan Perempuan dalam Gerakan Feminis Islam, (Sumenep; STIKA Press, 2009), 36.

11 Hal ini ditegaskan oleh Nabi Muhammad dalam sebuah haditsnya yang mengatakan bahwa tujuan diutusnya beliau ke dunia, tidak lain untuk menyempurnakan akhlak manusia; tradisi, budaya, dan kondisi sosial relegius masyarakat. Hadits ini diriwayatkan oleh imam Al-Bazzar, yang berbunyi "Sesungguhnya aku diutus untuk menyempurnakan akhlak yang mulia" (Seri Hadits Help File Online). Karenya, dalam sejarah perjuangan awal dakwah Islam, seringkali disebutkan beberapa peperangan antara umat Islam dengan suatu kerajaan tertentu; semisal Romawi, Persia, berikut juga dalam beberapa ekspansi penaklukan ke negara lainnya, semua itu dilakukan dengan
} 
Nabi Muhammad merupakan tokoh Islam pertama yang melakukan pemberdayakan kaum perempuan. ${ }^{12}$ Perempuan yang awalnya; masa jahiliyah, tidak dianggap sebagai jenis manusia, senantiasa diperbudak, diperjual belikan, dibunuh hidup-hidup, oleh Nabi Muhammad diposisikan sebagai orang terhormat. Bahwa Nabi menyerukan umatnya untuk menghormati ibu (perempuan) tiga kali lebih tinggi dari pada penghormatan pada seorang ayah (laki-laki). Sungguh merupakan satu gebarakan yang luar biasa.

Namun, nasib kaum perempuan kembali tenggelam setelah Islam melampaui masa kejayaannya; untuk tidak menyebut keburaman setelah ditaklukkan Bangsa Eropa, terpuruk dalam kemelut perang saudara, sehingga Islam memasuki masa "kegelapan". Sementara peradaban Eropa mulai bangkit memuncaki kejayaannya dengan mengadopsi pemikiran muslim. ${ }^{13}$ Dan sejak itu, peradaban Eropa mulai menjadi rujukan dunia dalam mengiterpretasi kemajuan dan perubahan dunia.

Feminisme, sebagai gerakan pemberdayaan perempuan yang diprakarasi orang-orang Barat, setelah mengalami kemajuan gemilang, lambat laun merambat dan berkembang di tengah-tengah dunia muslim. ${ }^{14}$ Harus diakui, bahwa pesatnya perkembangan konsep Feminisme telah sukses memberikan "kontribusi" perpecahan bagi internal umat muslim. ${ }^{15}$ Meski di lain sisi, kehadiran Feminisme Barat telah memberikan banyak inspirasi bagi sebagian besar kalangan muslim yang bosan melihat keterpurukan perempuan, dan menginginkan adanya "kesetaraan sejati" di antara sesama manusia, untuk kemudian bangkit dan melepaskan diri dari kungkungan diskriminasi.

Gerakan Feminisme, ketika masuk dalam lingkungan pemikiran umat Islam mendapat sambutan yang beragam. Bagi pemikir muslim yang mencoba meneropong melalui "kacamata" kesetaraan yang terpatri jelas dalam Al-Qur'an

satu alasan, menyampaikan syariat Islam, dan juga karena mereka selalu bertindak kejam terhadap warga negaranya. Hal ini bisa dilihat pada peperangan yang dilakukan khalifah Umar Bin Khattab dalam penaklukan Romawi di kota Yarmuk tahun 634 M, kota Syiria, dan beberapa kota lainya. Dikutip dari 1001 Kisah-Kisah Islam, Help File Online.

12 Hasil diskusi penulis dengan Aksin Wijaya, penulis buku Study Kontemporer Ulumul Qur'an, dalam acara bedah buku yang dilaksanan BEM Pi STIKAtanggal 23 Desember 2009.

13 Telaah Prof. Dr. Nasaruddin Umar, M. Ag., Membentuk Perempuan Berkualitas; Upaya Pemberdayaan Perempuan Melalaui Kaidah Spiritual, dalam Alimin Mesra, M.Ag., (Ed.), Membangun Kultur Ranah Perempuan; Reinterpretasi dan Aktualisasi, (Jakarta; Restu Ilahi, 2004), 165.

14 Muhammad Suhaidi, RB., “Dekontruksi Tafsir Gender Al-Qur'an; Telaah Kritis Atas Tafsir Feminin Aminah Wadud Muhsin dan Ashgar Ali Enggine," Skripsi, tidak diterbitkan, (Sumenep: STIKA, 2007), 129.

15 Perpecahan ini terjadi karena adanya perbedaan pemikiran mengenai upaya apa yang akan dilakukan untuk mewujudkan kebangkitan peradaban islam dalam menghadapi kemajuan peradaban Barat. Sebagian golongan mengatakan bahwa untuk meraih kejayaan islam harus menolak segala pemikiran yang dihembuskan pemikir eropa, karena hal itu merupakan agenda barat untuk melanggengkan hegemoninya bagi kalangan muslim. Sebagian lainnya mengatakan sebaliknya, mengadopsi pemikiran barat akan mempercepat kebangkitan peradaban muslim. selain kedua golongan tersebut, ada sebagain golongan yang bersifat moderat, tidak serta merta menolak maupun menerima pemikiran barat tersebut sebelum melakukan telaah mendalam pada pemikiran tersebut. Dikutip dari hasil diskusi materi Perkembangan PMDI yang diampu M. Maimun Syamsuddin, M.Ag., tahun akademik 2008-2009. 
dan Hadits, menanggapinya dengan luwes namun kritis. Tidak serta merta menerima maupun menolak tanpa menelaah terlebih dahulu secara mendalam.

Setelah melakukan telaah kritis pada konsep Feminisme Barat tersebut, lalu melahirkan satu teori gerakan Feminisme Islam. Terkait hal ini, Siti Muslihati memberikan gambaran tentang Feminisme Islam:

Secara umum, Feminisme Islam adalah alat analisis maupun gerakan yang bersifat historis dan kontekstual sesuai dengan kesadaran baru yang berkembang dalam menjawab masalah-masalah perempuan yang aktual menyangkut ketidakadilan dan ketidak sejajaran. ${ }^{16}$

Sementara itu, mereka yang menganggap pemikiran barat sebagai satu agenda global, proyek negara Eropa untuk melanggengkan hegemoni bagi negara muslim, menyatakan sikap antipati dan penolakan yang keras. ${ }^{17}$ Golongan ini mengatakan bahwa siapapun yang mengikuti pemikiran kaum Eropa, berarti dia telah keluar dari Islam.

Dengan demikian, munculnya isu Feminisme dikalangan barat, secara kasat mata, menjadi penyebab terbaginya kalangan muslim menjadi tiga golongan: pertama, pihak yang menerima secara utuh konsep Feminisme Barat, kedua, menerima secara kritis, lalu memadukan dengan konsep kesetaraan dalam Islam, dan ketiga, mereka yang menolak konsep Feminisme secara total. Golongan kedua itulah cikal bakal lahirnya konsep Feminisme Islam.

\section{Fokus Gerakan Feminisme Islam;}

\section{Mempertahankan Kodrat, Mengembangkan Potensi}

Diakui memang, Feminisme lahir dari peradaban barat. Karenanya banyak orang yang merasa takut untuk turut serta dalam gerakan ini. Namun, bila kita kaji secara mendalam, maka akan ditemukan perbedaan konsep Feminisme Barat dengan konsep Feminisme Islam. Sebab Feminisme Islam telah mengalami perombakan total (dekontruksi pemikiran), dengan memasukkan beberapa nilainilai keislaman, batasan-batasan, dan sesuai dengan ajaran Islam.

Perbedaan tersebut bisa dilihat pada objek, wacana yang dikembangkan, dan konsentrasi gerakan dalam mengupayakan kesetaraan bagi perempuan. Feminisme Barat; terutama yang radikal, telah jauh melampaui batasan-batasan kodrat seorang perempuan. Semisal, mereka sama sekali tidak mau berhubungan (menikah) dengan laki-laki, tidak mau mengandung, melahirkan, dan juga menyusui.18 Sebab bagi mereka, kesejahteraan perempuan diyakini hanya bisa diraih setelah menaklukkan laki-laki, atau paling tidak menyamai tindakan yang dilakukan laki-laki.

\footnotetext{
16 Tuntaskan pada Siti Muslihati, Feminisme dan Pembedayaan Perempuan dalam Timbangan Islam (Jakarta: Gema Insani Press, 2004), 47.

17 Lebih jauh periksa Abdul Mustaqim MA., Tafsir Feminis..., 31.

18 Tuntutan tersebut bagi kalangan muslim telah jauh melampaui garis kodrat yang ditentukan Tuhan, yaitu: perempuan secara bilogis bertugas untuk hamil, melahirkan, dan menyusui, karena selain perempuan (laki-laki) tidak bisa hamil. Lihat skripsi Muhammad Suhaidi RB., Dekontruksi Tafsir Gender..., 28.
} 
Sementara Feminisme Islam, berupaya memberdayakan perempuan pada skala sosio-kultural (memperjuangkan kesetaraan Gender). Menuntut adanya kesejajaran, kesamaan hak, tanpa diskriminasi, penindasan, maupun pengucilan perannya dilingkup sosial kemasyarakatan. Sebab, bagi kalangan feminis muslim, menstruasi, mengandung, melahirkan, dan menyusui (perbedaan jenis kelamin; seks), merupakan kodrat yang harus diterima. Namun demikian, perbedaan jenis kelamin tidak boleh dijadikan alasan untuk mendiskriminasi seseorang. ${ }^{19}$

Adanya gerakan Feminisme Islam tersebut, tiada lain karena adanya kesadaran bahwa Islam sangat menjunjung kesejajaran status (kesetaraan gender) antara laki-laki dan perempuan. Tidak ada yang lebih istimewa diantara keduanya. Mereka memiliki potensi, hak, dan tugas yang sama sebagai khalifah Tuhan di muka bumi. Dengan demikian, tidak ada alasan yang membenarkan pembatasan peran seseorang, dengan berdasarkan jenis kelamin maupun golongan tertentu. Karena itu, lahirlah konsep Feminisme Islam yang berupaya mewujudkan kesetaraan yang telah diajarkan oleh Tuhan dalam agama Islam.

Tentang tujuan, berikut citi-ciri dari Feminisme Islam, Abul Mustaqim merumuskannya sebagai berikut:

1. Feminisme Islam harus mendasarkan diri kepada agama. Feminis muslim harus menyadari bahwa agama Islam dan ajarannya (Al-Qur'an dan Hadits) adalah sumber nilai dan pendukung yang terbaik dalam perjuangannya. Feminisme Islam harus senantiasa merujuk pada prinsip-prinsip ajaran alQur'an dan Hadits sebagai sumber nilai tertinggi dan prilaku Rasulullah SAW. adalah contoh yang paling baik dalam melakukan gerakan.

2. Feminisme Islam mestinya tidak bersifat chauvinistik. Kaum feminis tidak boleh hanya menekankan kekuatannya kepada perempuan dan mengabaikan potensi kekuatan laki-laki, ataupun justru berusaha meruntuhkannya. Lai-laki dan perempuan diciptakan oleh Tuhan sebagai mitra, bukan sebagai musuh atau lawan (rival) dalam persaingan. Sehingga keduanya, dapat saling membantu, melengkapi satu sama lain, serta dapat bersatu secara harmonis dalam menegakkan nilai-nilai keadilan dan kebenaran.

3. Feminisme Islam harus memandang ajaran Islam secara integral dan menyeluruh. Al-Qur'an dan tradisi Islam yang muncul dalam sejarah, dapat dijadikan sebagai pisau analisis dalam memecahkan persoalan yang sedang dihadapi. Sudah barang tentu, harus tetap mempertimbangkan konteks sosiokultural pada waktu itu. ${ }^{20}$

Untuk itu, fokus gerakan kaum Feminisme Islam adalah dengan menghadirkan corak penafsiran yang baru terhadap doktrin-doktrin agama yang selama ini, oleh kalangan tertentu ditafsiri secara serampangan, sehingga wajah Islam bagi kaum perempuan begitu suram dan menakutkan. Melalui corak dan metode penafsiran yang baru, di tangan kaum Feminis muslim, agama ditampilkan dengan wajah yang ramah, peduli pada keberlangsungan kehidupan

\footnotetext{
19 Abd. Warits, Nilai-Nilai PendidikanPemberdayaan Perempuan dalam Novel Perempuan Berkalung Sorban Karya Abidah el-Khaliqy, (Sumenep: Instika Press, 2012), 126.

${ }^{20}$ Lihat Abdul Mustaqim MA., Tafsir Feminis..., 35-36.
} 
perempuan, lalu menjadikan mereka sebagai manusia yang memiliki harkat, martabat dan posisi yang sama dengan laki-laki.

Dengan demikian, para Feminis muslim telah melakukan satu terobosan baru, begitu strategis dalam melawan tradisi patriarkhi yang ditimbulkan oleh adanya pemahaman yang tidak utuh terhadap teks Al-Qur'an dan Hadits, sehingga amanat kesetaraan, kesejajaran antara laki-laki dan perempuan tidak nampak kepermuakaan.

Dilain pihak, para Feminis muslim terus melakukan gerakan, dengan menjadikan isu keagamaan sebagai konsentrasi gerakan sebagai upaya menyadarkan akan posisi dan fungsi kaum perempuan secara lebih terbuka. Dengan cara menawarkan konsepsi penafsiran keagamaan yang lebih berorientasi kesetaraan, sesuai dengan nilai-nilai ideal Al-Qur'an dan Hadits, tentang makna pentingnya kesetaraan, kesederajatan, dan persamaan tanpa diskriminasi akibat perbedaan jenis kelamin.

\section{Feminisme Islam dan Pendidikan Pemberdayaan Perempuan}

Pada dasarnya, gerakan pemberdayan perempuan (Feminisme; terlebih Feminisme Islam) berjalan beriringan dengan proses pendidikan. Sebab, sejatinya pendidikan bertujuan melahirkan sosok manusia yang berdaya, mandiri, terbebas dari ketidakberdayaan, serta mampu memberikan manfaat bagi lingkungan sekitarnya. Hal ini jugalah yang menjadi spirit dari gerakan Feminisme Islam, mengingkan adanya kaum perempuan yang berdaya, mandiri, berkreativitas dan terbebas dari diskriminisi lingkungan sekitanya. Hanya saja gerakan feminis terfokus pada kaum perempuan dan tidak bagi laki-laki.

Secara konsep, pendidikan memang mengajarkan (menekankan) bahwa manusia memiliki status, kedudukan, dan kesempatan yang sama (setara) bagi manusia. Namun, pada tataran realitas hal itu tidak terjadi, pendidikan tidak mampu mewujudkan kesetaraan tersebut. Bahkan, awalnya pendidikan justru tidak diperuntukkan bagi kalangan perempuan. Pendidikan hanya bisa dinikmati oleh laki-laki. Kalaupun pada akhirnya mereka bisa mengenyam pendidikan, namun hal itu tidak lebih dari pendidikan dasar, dan tetap saja terbatasi. Tidak seperti laki-laki yang bisa menempuh pendidikanya tanpa dibatasi oleh apapun. ${ }^{21}$

Oleh karenanya, ketika para pemikir muslim menyadari bahwa pendidikan hanya mampu mengajarkan (memberitahukan) adanya kesejajaran dan keseteraan bagi seluruh manusia, tapi tidak mampu mewujudkannya dalam kehidupan nyata, lalu mereka berupaya memperjuangkan kesetaraan tersebut bagi perempuan melalui gerakan Feminisme.

Oleh karenanya, kalangan Feminis muslim yang menyadari akan hal ini; ketidakberpihakan pendidikan bagi perempuan, lalu melakukan gerakan pemberdayaan bagi kaum perempuan melalui upaya penyadaran, pemberdayaan dan penanaman kreativitas bagi kaum perempuan. Tidak hanya itu, kaum Feminis muslim juga melakukan reinterpretasi pada beberapa teks (Al-Qur'an dan

${ }^{21}$ Dikutip dari makalah Abd. Warits, Dibalik Ketabahan Seorang Ibu..., 1. 
Hadits) yang berkaitan dengan kehidupan perempuan yang selama ini diyakini sebagai salah satu penyembab terpuruknya kaum perempuan.

\section{Ragam Peranan Kaum Perempuan; Perjuangan Menuju Kesetaraan}

Klasifikasi peran perempuan dalam pembahasan ini tidak bermaksud memilah, apalagi menentukan kadar kehormatan dari beberapa jenis peranan tersebut. Klasifikasi ini dimaksudkan untuk menggambarkan peranan perempuan secara lebih mendetail.

Secara garis besar, peran perempuan dapat dibedakan menjadi beberapa bagian, antarai lain:

Petama, peran perempuan di ranah publik. Sejarah mencatat peranan perempuan di ranah publik, meski masih belum sempurna dan final,22 mengalami peningkatan yang begitu signifikan. Kondisi ini bisa dilihat pada jumlah keterlibatan kaum perempuan di kancah politik, dan proses perubahan sosial, yang terus bertambah.

Keterlibatan politk kaum perempuan sudah mendapatkan porsinya yang memadai. Tidak ada lagi larangan bagi kaum perempuan untuk berkiprah di kancah politik. Bahkan Negara telah menentukan porsi minimal $30 \%$ keikutpesertaan kaum perempuan dalam even perpolitikan negeri ini. Keputusan tersebut merupakan kesadaran politik warga indonesia atas peran pentingnya kaum perempuan demi mewujudkan tatanan dan pembangunan bangsa ini agar lebih baik.

Selain di kancah politik, perempuan juga semakin aktif berperan sebagai komando beberapa Lembaga Sosial Kemasyarakat, semisal Lembaga Swadaya Masyarakat (LSM), Organisasi Kemasyarakat, Organisasi Keagamaan, yang tidak jarang di dalamnya beranggotakan laki-laki.

Kedua, sebagai pendidik. Secara sederhana, peran ini dilakukan seorang perempuan sebagai ibu bagi anak-anaknya. Sosok yang paling berperan sebagai peletak pendidikan pertama bagi anak. Anak yang cerdas, kreatif, tangkas pasti karena dididik oleh seorang ibu yang juga cerdas: mengerti kondisi jiwa anaknya, mampu menyelam ke dalam dunia mereka yang masih bersih dan jernih, lalu menanamkan nilai-nilai sifat kearifan. ${ }^{23}$

Ibu yang kreatif, mampu membekali anaknya dengan banyak skill kreativitas. Sehingga, ketika anak tersebut dewasa, anaknya akan tumbuh dengan potensi beragam. Hal ini disebabkan tingkat kecendrungan anak-anak sangat kuat untuk

22 Ketidak sempurnaan ini, karena diberbagai tempat masih terdapat tindakan diskriminatif bagi perempuan. Satu sisi, mimpi menghapus diskriminasi yang selama ini menjadi motivasi terbesar pejuang kaum perempuan sulit dicapai. Sebab, prilaku positif dan negatif akan terus bejalan beriringan sebagai komposisi keseimbangan dunia. Namun demikian, bukan berarti kita harus diam bila melihat ada tindakan atau kasus yang menyakiti orang lain. Periksa, KH. Husien Muhammad, Islam Agama..., 171.

${ }^{23}$ Kedekatan seorang ibu dengan anak akan senantiasa membekas dalam memori otaknya, karena itulah segala sesuatu yang berkaitan dengan prilaku ibu akan diikuti sang anak. Ibu yang bisa menyayangi, bercanda dan bermain bersamanya, akan membuat sang anak patuh dan hormat padanya. Tuntaskan pada Dr. Muhammad Ali Al-Hasyimi, Jati Diri Wanita Muslimah (terj), (Jakarta: Pustaka Al-Kautsar, tanpa tahun), 203. 
meniru apa yang ditangkap panca indranya. ${ }^{24} \mathrm{Ibu}$, dalam hal ini yang paling sering dan dekat dengan anak, akan menjadi bagian tak terlewatkan dari pengawasan anak. Jadi, apapun yang dilakukan ibu senantiasa akan membekas dalam benaknya, sekaligus akan ditiru oleh sang anak.

Pendidikan yang ditanamkan seorang ibu memang berbeda dengan sistem pendidikan sekolah. Seorang ibu mengenalkan nilai-nilai kehidupan, bukan teori yang seringkali kita agungkan. Lewat tingkah lakunya sehari-hari, gaya bicara, sekaligus cara menangani persoalan yang menimpanya, sang ibu menberikan contoh baik bagi anak-anaknya sekaligus mengajarkan bagaimana kelak ketika ia dewasa mesti bertindak. ${ }^{25}$

Untuk itu, latar belakang pendidikan seorang ibu akan sangat mempengarui proses pendidikan bagi anaknya. Hal itu akan berefek pada perjalanan pendidikan anak di masa mendatang. Pastinya, seorang ibu dengan latar belakang pendidikan yang tinggi akan mempunyai cara berbeda dalam mendidik anak, bila kita bandingkan dengan mereka (para ibu) yang berpindidikan rendah, apalagi sama sekali belum mengenal pendidikan.

Karenanya, nasib generasi penerus sebuah bangsa berada pada kelihaian tangan seorang perempuan; ibu, dalam menanamkan nilai dasar pendidikan bagi anak-anaknya.

Ketiga, peran di lingkungan rumah tangga. Perempuan dalam hal ini kapasitasnya sebagai seorang istri. Namun meski demikian, jangan berpikir bahwa istri dalam bingkai rumah tangga, hanya berfungsi sebagai pembantu, atau pemuas laki-laki. Sebab corak pikiran semacam itu, disadari atau tidak telah menodai kesucian ikatan pernikahan yang dianjurkan Nabi Muhammad.

Mereka adalah patner suami yang tidak bisa direndahkan perananya dalam bingkai keluarga. Hubungan antara suami dan istri merupakan jenis hubungan kemitraan-kesejajaran yang saling mempengaruhi, membutuhkan, dalam mewujudkan keluarga sakinah.

Meski memang, saat ini predikat pemimpin dalam lingkaran keluarga masih didominasi oleh laki-laki. Tapi menurut M. Quraisyi Shihab, sebagaimana yang dikutip Hamdani, kepemimpinan tersebut tidak bisa mengantarkan laki-laki pada kesewenang-wenangan dalam bertindak. Sebab, Islam dengan tegas memerintahkan adanya diskusi, musyarawah setiap kali akan mengambil sebuah keputusan. Kepemimpinan seorang suami tidak sampai menghilangkan hak istri untuk ikut serta dalam menentukan kebijakan dalam keluarga. ${ }^{26}$

Bila ditelaah secara mendalam, perempuan memiliki peran yang cukup penting dalam memberikan pengaruh lahirnya sebuah "keputusan" atau penentuan kebijakan yang akan diambil oleh seorang suami. Hal ini telah dicontohkan oleh Nabi Muhammad sendiri, ketika beliau merasa "kecewa"

24 Dr. Muhammad Ali Al-Hasyimi, Jati Diri Wanita Muslimah (terj), (Jakarta: Pustaka Al-Kautsar, tanpa tahun), 211- 213.

${ }^{25}$ Dr. Muhammad Ali Al-Hasyimi, Jati Diri Wanita Muslimah (terj), (Jakarta: Pustaka Al-Kautsar, tanpa tahun), 204-208.

26 M. Quraishi Shihab, Kesetaraan Dalam Islam, dalam Hamdani, M.Ag., Masyarakat Patriarkhi dan Perubahan Keluarga Muslim, (Jakarta; Restu Ilahi, 2004), 247-248. 
setelah meliahat tidak ada kaum muslimin yang memotong hewan kurban dan melepas kain ihram. Kemudian beliau mendatangi rumah istrinya, Ummu Salamah. Saat itu, Ummu Salamah menyarankan agar Nabi menyembelih hewan kurbannya di hadapan kaum muslimin. Akhirnya, Nabi mengambil keputusan atas anjuran istinya tersebut, dan kaum muslimin pun serentak menyembelih hewan kurban bersama Nabi. ${ }^{27}$

Kondisi ini tidak jauh berbeda dengan situasi yang ada di Indonesia. Dalam artian, seorang istri yang cerdas, baik, dan tangguh akan mampu menghantarkan karir suaminya yang pada tingaktan paling gemilang. Meski juga sebaliknya, seorang istri yang "bejat" akan mudah pula membawa suaminya kejurang kehancuran. Telah banyak para pejabat negeri ini, yang "terpaksa" korup demi melayani gaya hidup istri tercinta.

Dengan demikian, istri dalam bingkai rumah tangga yang akan sangat menentukan kesuksesan perjuangan seorang suami.

Keempat, peran sebagai pelaku ekonomi. Asgar Ali Engginer menjelaskan bahwa pada dasarnya semua perempuan bebas memilih mau berperan, berprofesi di mana dan apa saja. Dengan catatan tidak melangkahi batasan-batasan yang telah ditetapkan Allah. ${ }^{28}$ Terkait peran dalam persoalan ekonomi (mencari nafkah), bekerja di luar rumah, hal ini memang sempat menjadi perdebatan yang cukup panjang. Sebab, dalam Al-Qur'an terdapat ayat yang menganjurkan agar hendaknya perempuan tinggal di dalam rumah. ${ }^{29}$

Menyikapi isi pernyataan ayat tersebut, muncul beberapa golongan dengan pendapat yang berbeda. Golongan pertama berkesimpulan, bahwa perempuan seharusnya (wajib) tinggal dirumah, dan tidak boleh pergi keluar rumah kecuali atas idzin suami, dan harus didampingi seorang mahram. Sementara golongan kedua, hendaknya perempuan bersenang-senang saja di rumah, tidak perlu berkeliaran keluar rumah. Sedangkan, golongan ketiga mengatakan, ayat tersebut bukan berarti perempuan sama sekali tidak boleh keluar dari rumah, melainkan sebagai isyarat yang halus bahwa perempuan lebih penting peranannya dalam menyelesaikan persoalan keluaga. ${ }^{30}$

Sementara Muhammad Qutub justru menegaskan bahwa ayat tersebut tidak bisa dijadikan landasan hukum untuk melarang perempuan bekerja di luar rumah. Hanya saja, Islam memang tidak mendorong perempuan berperan sebagai penopang ekonomi keluarga. Sebab, hal itu adalah tugas penuh seorang suami.

27 Lihat Laili Salimah, Rekontruksi Aplikasi Teori Emansipasi Wanita, dalam Dr. Jainal Aripin, MA...,(ed.), 81.

28 Asgar Ali Engginer, Hak-Hak Perempuan dalam Islam, Farid Wajdi dan Cicik Farkha Assegaf (penj.), judul asli The Righ Of Women in Islam, (Jogjakarta; Lembaga Studi dan Pengembangan Perempuan dan Anak), 136.

${ }^{29}$ Hal ini terdapat dalam QS. Al-Ahzab: 33, yang artinya berbunyi “33. Dan hendaklah kamu tetap di rumahmu dan janganlah kamu berhias dan bertingkah laku seperti orang-orang Jahiliyah yang dahulu dan dirikanlah shalat, tunaikanlah zakat dan taatilah Allah dan Rasul-Nya. Sesungguhnya Allah bermaksud hendak menghilangkan dosa dari kamu, Hai ahlul bait dan membersihkan kamu sebersih-bersihnya.

30 Perdeatan mengenai boleh tidaknya perempuan keluar rumah (bekerja mencari nafkah) dibahas panjang lebar dalam Alimin Mesra, M.Ag., Peran Perempuan dalam Keluaga; Kepemimpinan, Domestikasi, dan Peran Ganda, (Jakarta; Restu Ilahi 2006), 205-208. 
Namun demikian, ketika nafkah suami tidak bisa mencukupi kebutuhan keluarga, maka Islam membenarkan perempuan berkeja. ${ }^{31}$

Aminah Wadud memberikan komentar berbeda. Menurutnya yang dilarang dalam ayat tersebut adalah keluar rumah dengan maksud memamerkan diri. Dan larangan tersebut pada dasarnya tidak diarahkan pada jenis kelamin tertentu. Meskipun ia laki-laki, namun bila tujuannya keluar rumah adalah untuk memamerkan diri sendiri hukumnya tetap tidak boleh. ${ }^{32}$

Terlepas dari perbedaan pandangan beberapa tokoh tersebut di atas, yang jelas Islam hadir dengan suatu konsepsi hubungan manusia yang berlandaskan keadilan, kesamaan status dan kedudukan di antara laki-laki dan perempuan. Tidak hanya dalam lingkup peribadatan; mendapatkan pahala, namun juga dalam persoalan ekonomi.

Dengan tegas, Islam memberikan hak kepemilikan terhadap sejumlah harta, dan suami ataupun bapaknya tidak mempunyai hak untuk menggunakannya dengan semena-mena. Baik harta tersebut diperoleh melalui pembagian harta warisan, maupun melalui usahanya sendiri. ${ }^{33}$

Sementara itu, ketika menilik pada fakta sejarah, peran ini telah dilakukan kaum perempuan, terutama di negara Arab sejak Nabi Muhammad belum mendapatkan wahyu. Perempuan telah terbiasa mengelola usaha dagang, sejak berabad-abad yang lalu. Namun, masih terbatas pada kalangan tertentu saja, semisal keturunan bangsawan, atau keturunan saudagar kaya. ${ }^{34}$

Bisnis kaum perempuan yang dijalankan pada masa jahiliyah, bisa dilihat pada kiprah Siti Khatijah, seorang saudagara kaya dan keturunan bangsawan. Perempuan yang disegani di tanah Arab. Dapat dikatakan, tidak ada kalangan masyarakat Arab yang berani bertidak kurang ajar padanya. Beliau menjalani bisnis perdagangannya jauh sebelum Muhammad diangkat menjadi Rasul.

${ }^{31}$ Keterangan lebih lanjut dapat ditelusuri M. Quraisyi Shihab,Wawasan Al-Qur'an, (Bandung; Mizan, 1996), 305.

32 Aminah Wadud Muhsin, Qur'an Menurut Perempuan; Meluruskan Bias Gender dalam Tradisi Tafsir, Abdullah Ali, (Penj). Judul asli Qur'an an Women; Rereading The Secret Text From a Women's Prepective, (Jakarta; PT Serambi Ilmu Semesta), 166.

33 Kesimpulan ini diambil dari bunyi QS. Annisa' ayat 32 yang artinya: Dan janganlah kamu iri hati terhadap apa yang dikaruniakan Allah kepada sebagian kamu lebih banyak dari sebagian yang lain. (karena) bagi orang laki-laki ada bahagian dari pada apa yang mereka usahakan, dan bagi Para wanita (pun) ada bahagian dari apa yang mereka usahakan, dan mohonlah kepada Allah sebagian dari karunia-Nya. Sesungguhnya Allah Maha mengetahui segala sesuatu. Periksa, Muhammad Taufik Hidayat, M. Ag., Integrasi atau Marginalisasi;Pembangunan dan Status Perepuan, dalam Alimen Mesra (ed.), Membangun Kultur..., 285.

${ }^{34}$ Kondisi ini terjadi karena fanatisme keluarga, kabilah atau kesukuan, yang begitu kental ditanah Arab. Bagi kalangan masyarakat jahiliyah, seorang perempuan keturunan bangsawan memang mendapat kedudukan yang sedikit lebih istimewa dari pada para perempuan lainnya. Meski memang, hak-hak mereka dalam hidup masih tetap saja terabatas. Tidak sempurna sebagaimana laki-laki. Namun bila dibandingkan dengan perempuan lainnya, nasib perempuan kaum bangsawan lebih mujur dari pada perempuan biasa, atau perempuan berstatus budak. Dalam fersi sejarah yang berbeda disebutkan, bahwa perempuan keturunan bangsawan juga bisa keluar rumah tanpa dikawal keluarganya (berjalan sendirian), dan juga memiliki hak berpendapat. Hal ini dikarenakan, kekuatan atau status kebangsawanan keluarganya, menyebabkan ia terlidung dari gangguan orang lain. Dikutip dari 1001 Kisah Islam, Help File Online. 
Bahkan, sejarah mencatat, para saudagar perempuan itu juga mempekerjakan laki-laki, sebagaimana Nabi Muhammad yang bermitra dengan Siti Khatijah.

Pada perjalanan selanjutnya, kita bisa melihat munculnya tokoh-tokoh perempuan yang hebat dalam mengelola perekonomian. Termasuk juga kalangan perempuan di Indonesiam semisal: Sri Mulyani; terlepas dari beberapa kontroversi kebijakannya, mentri ekonomi Indonesia selama dua periode 20042009 dan periode 2009-2015. Nalurinya yang kuat dalam melakukan analisa keuangan diakui banyak kalangan, hingga akhirnya ia ditarik menjadi salah satu direktur Intenational Monetare Found (IMF) pada paruh pertengahan 2010 lalu.

Memang dalam realitas sehari-hari saat ini, kita akan mudah melihat kiprah perempuan yang membantu suami mencari nafkah guna menopang ekonomi keluarganya. Mereka bekerja bersama laki-laki, mencari penghidupan untuk keluarganya. Meski dalam hal ini, Islam memang mengamanatkan kewajiban mencari nafkah hanya pada suami(laki-laki). Namun demikian, Islam tidak pernah memberikan larangan bagi perempuan untuk bekerja mencari penghasilan.

Ironisnya, bagi mereka yang bekerja sebagai buruh, atau pejabat bawahan di sebuah perusahaan tertentu, seringkali mendapat jatah upah lebih kecil dari pada laki-laki. Padahal, waktu yang dihabiskan selama bekerja tidak ada bedanya dengan laki-laki. Bahkan terkadang, daya produktivitasnya justru melampaui laki-laki. Entah pertimbangan apa yang menyebabkan mereka mendapatkan upah yang lebih kecil. Berdasarkan sepengetahuan penulis, dalam masyarakat kita terdapat keyakinan bahwa daya produktivitas laki-laki jauh melebihi perempuan. Hal ini dikarenakan laki-laki memiliki otot dan semangat kerja melebihi perempuan. ${ }^{35}$

Padahal, bila kita menelaah secara mendalam, anggapan semacam itu sama sekali tidak benar. Terlalu mudah bila kita berkeinginan menemukan perempuan yang memiliki ketangguhan kerja melebihi laki-laki. Mungkin benar, sifatnya kasuistik. Namun bila demikian, lalu mengapa ketika memberikan upah, menggunakan patokan semua perempuan adalah lemah?

Kondisi yang sama dapat pula kita temui pada para perempuan yang tinggal di daerah pesisir. Tidak segan-segan mereka bekerja sebagai buruh kapal, dengan mengangkut/memikul ember besar yang berisi penuh ikan dari hasil tangkapan kapal. Mereka membawa ikan dari tengah laut, menuju pelabuhan untuk dipasarkan.

Selain itu, Mereka begitu lihai dalam mengelola pemasaran ikan. Keahlian tawar-menawar dalam transaksi jual-beli, tidak bisa ditiru/dikalahkan oleh lakilaki. Dan tak bisa dipungkiri, hampir seluruh pasar tradisional, terutama di

\footnotetext{
35 Keyakinan semacam itu mudah kita dapatkan, tetutama di pelosok-pelosok desa. Keyakinan masyarakat ini merupakan sisa dari budaya patriarkhi yang hingga kini masih bertahan. Namun, secara perlaahan-lahan keyakinan itu semakin memudar seiring dengan terbukanya cakrawala berpikir masyarakat. Kurang lebih seperti itulah yang terjadi dilingkungan penulis. Namun hingga kini, upah buruh perempuan masih tetap lebih rendah dari laki-laki. Entah kapan ketidak adilan ini bisa berakhir. Ironisnya, masyarakat menerima semua itu dengan hati lapang dan ikhlas.
} 
Madura, perempuan adalah pelaku dan pengelolanya. Merekalah pelaku ekonomi yang pantas diteladani.

Uraian beberapa fakta tersebut diatas, secara tidak langsung telah membantah bahwa perempuan memiliki kemampuan fisik di bawah laki-laki. Buktinya, mereka juga bisa melakukan beberapa pekerjaan yang dilakukan laki-laki. Karena itu, ketidakadilan semacam inilah yang perlu diluruskan, dan inilah konsen dari gerakan Feminsme Islam. Meski terkadang, mereka yang berprofesi sebagai buruh, tidak hanya perempuan yang bernasib buruk, tapi juga laki-laki pun yang berprofesi sebagai buruh memiliki nasib yang sama. ${ }^{36}$

\section{Inti Gerakan: Kesetaraan; Bukan Merampas Kekuasaan}

Sejatinya, kurang pantas bila kita masih saja mengatakan bahwa perempuan masih terkunkung dalam ketidakberdayaan. Sebab, perempuan telah mendapatkan hak-hak hidupnya sebagai manusia yang sama dengan laki-laki. Sudah tidak ada lagi, orang yang tidak bisa berpartisipasi aktif dalam pemilu. Baik sebagai pemilih, atau sebagai calon yang akan terpilih. Tidak ada lagi manusia yang tidak bisa sekolah lantaran ia perempuan. Atau, tidak ada lagi manusia yang dilarang berdagang, bekerja, karena ia perempuan.

Perempuan sudah mendapatkan apa yang dia inginkan. Kesetaraan, kesejajaran, kebebasan, dan peluang untuk menjadi tokoh hebat yang akan dicatat sepanjang sejarah, pintu itu sudah terbuka lebar. Meski memang, posisi perempuan masih belum mencapai titik kesempurnaan. Tapi inilah kehidupan, memang tidak ada yang sempurna. Karena memang Tuhan menciptakan manusia untuk menyelesaikan "pekerjaan" Tuhan di muka bumi yang memang sengaja tidak diselesaikan.

Mungkin benar, manusia memang tidak pernah puas dengan apa yang telah didapatkannya. Setelah mendapatkan keinginananya, lalu muncul keinginan lain yang lebih tinggi. Manusia selalu serakah, ingin mendapatkan semua yang terlintas dalam pikirannya. Dan sikap serakah ini amat sulit dihilangkan. Jadi tidak heran, bila dalam Al-Qur'an seringkali diceritakan secara berulang-ulang tentang keserakahan suatu kaum, dan akibat keserahan tersebut mereka dimusnahkan.

Dalam hal ini (pemberdayaan perempuan), penulis menemukan indikasi yang serupa terhadap arah perjuangan kaum Feminisme dalam memberdayakan perempuan. Mengapa? Tidak sedikit kaum feminis yang selalu meneriakkan agar perempuan menjadi orang "sukses" dengan tampil sebagai wanita karir, meninggalkan tugas rumah tangga, yang mereka (kaum feminis) asumsikan sebagai salah satu bentuk kejumudan seorang perempaun. Bagi mereka, sebelum kaum perempuan menjadi wanita karir dalam jumlah yang banyak, perjuangan Feminisme masih belum bisa dikatakan sukses.

\footnotetext{
${ }^{36}$ Nasib buruh di indonesia memang seringkali kehilangan hak-hak mereka sebagai pekerja. Hal ini juga menjadi konsentrasi tersendiri bagi kalangan pemerhati persoalan sosial. Lihat Soerjono Soekanto, Sosiologi Penyimpangan, (Jakarta; Rajawali, 1988).
} 
Tersebabnya, tidak sedikit diantara mereka yang "tega" meninggalkan anak dan keluarganya demi mengejar karir pribadinya. Akhirnya, keluarganya menjadi kacau dan berantakan. Anak-anaknya yang merasa kekurangan perhatian dari kedua orang tuanya, kemudian mencari perhatian di luar rumah. Maka dari itu, sangat banyak remaja yang terjebak kasus pergaulan bebas: narkoba, suka tauran, free seks dan tindakan amoral lainnya. Ini merupakan satu akibat disharmonisasi pemberdayaan perempaun. ${ }^{37}$

Memang, tugas mengasuh anak bukan serta merta tanggung jawab seorang istri. Melainkan keduanya; suami dan istri, harus berperan aktif dalam meberikan kasih sayang, perhatian, dan pendidikan bagi anaknya. Namun, bagaimana hal itu bisa dilakukan bila keduanya jarang sekali berkumpul dengan anak dan keluarganya. Penulis tidak sanggup membayangkan bagaimana nasib generasi Bangsa kita bila semua anak-anak ditingalkan orang tuanya, hanya demi mengejar karirnya masing-masing.

Tidak sedikit dari akibat emansipasi wanita yang mulai menampakkan gejala "over" ini, banyak bermunculan kasus perselingkuhan dan perceraian. Kenapa? Karena tidak ada lagi yang berperan sebagai tokoh figur di internal keluarga tersebut. Semua merasa berhak menjadi yang paling benar, sehingga tidak pernah lagi menemukan titik kesepakatan. Sungguh, Feminisme Islam dalam meperjuangkan hak-hak perempuan tidak memiliki tujuan yang semacam itu.

Melihat realitas diatas, tanpaknya kita mesti sepakat dengan keputusan pihak yang dulunya tidak setuju dan menolak ide Feminisme. Mungkin, ketakukan dan kekawatiran akan rusaknya relasi di internal rumah tangga itulah, yang menjadi salah satu alasan penolakan tersebut. Meski harus diakui pula, kehadiran konsep feminis cukup banyak memberikan pencerahan, kebebasan, dan peluang bagi perjalanan kaum perempuan untuk mengabdi sebagai jenis manusia yang utuh. Memang, sesuatu apapun tidak akan pernah lepas dari efek positif dan negatifnya. Semua sudah menjadi keteraturan alam yang tidak bisa dihindari.

Bagi penulis, kondisi ini tidak bisa dibiarkan. Toeri Feminisme, terlebih konsep Feminisme Islam, harus mengalami perombakan dan pengbongkaran (dekontruksi) signifikan. Mungkin dengan begitu, akan terjadi keseimbangan dalam perjalanan kaum perempuan ke depan. ${ }^{38}$ Sebab, memosisikan perempuan sebagai orang yang kuat, cerdas, dan berani, belum bisa menutup kemungkinan akan adanya pelecehan, dan tindakan tidak manusiawi lainnya oleh laki-laki bagi perempuan.

Untuk itu, arah perjuangan pejuang feminis sudah saatnya diarahkan ke pihak laki-laki. Berikan mereka kesadaran, bahwa perempuan adalah bagian dari

37 Ada banyak faktor kenakalan remaja yang menyebabkan mereka tidak terkendali, lihat pad, http:// bbawor.blogspot.com/2008/08/kenakalan-remaja-dan-faktor-faktor-yang.html. tgl 21 juli 2009.

38 Kenyataan bahwa kaum perempuan telah bangun dari tidur panjangnya melalui lahirnya feminisme tanpaknya beebuntu panjang. Masyarakat terlalu jauh tenggelam dalam euforia feminis. Sehingga mereka tidak menyadari, bahwa mengasuh anak-anak yang kelak akan menjadi penerus bangsa dan agama adalah bentuk lain dari emansipasi wanta. Tuntaskan pada Laili Salimah, Rekonstruksi Aplikasi..., 82. 
manusia yang sama dengan dirinya, yang harus dihargai, dihormati, dikasihi, dan disayangi. Begitu juga perempuan, seberapapun suksesnya karir yang ia titi, tidak boleh menyepelekan kaum laki-laki.

\section{Penutup}

Harus kita akui, bahwa sejatinya Islam telah memberikan hal terbaik untuk perempuan, Islam juga telah menghantarkan perempuan pada derajat dan posisi yang setara dengan laki-laki. ${ }^{39}$ Laki-laki dan perempuan, suami dan istri, muslim dan muslimah itu memiliki kedudukan yang sama di hadapan Tuhan. Sehingga tidak seorang pun di antara makhluk Tuhan itu yang boleh menindas dan merendahkan antara satu dengan lainnya.

Hanya saja, masih banyak kalangan yang enggan mengakui hal tersebut. Ini serta merta disebabkan sejarah penindasan kehidupan perempuan yang begitu lama dan masif diwariskan dari generasi ke generasi. Akibatnya, pesan keseteraan yang begitu langtang disuarakan oleh Islam, bahkan perintah Nabi untuk menghormati kaum Ibu (perempuan) tiga kali lebih tinggi dari ayah (laki-laki) tak terpahami dengan baik.

Kesetaraan yang dimaksud di atas, sekiranya dapat dipahami bahwa ada pembagian tugas yang jelas antara laki-laki dan perempuan. Sebagai patner yang saling melengkapi, saling membutuhkan, dan tidak boleh ada yang boleh menyepelehkan satu dengan yang lain. Yang pasti semua jenis pekerjaan, pada dasarnya memiliki kadar kehoramtan yang sama. Fenomena "tuan-pelayan" selamanya akan tetap ada, tidak mungkin bisa dihapus. Karena semua manusia Tidak mungkin bisa menjadi "tuan".

Namun demikian, perbedaan status antara "tuan" dan "pelayan" bukan berari harus melakukan "pembedaan" dalam hal pemenuhan hak dan kewajiab diantara manusia. Semua itu, tetap tidak menyebabkan bolehnya bertindak diskriminasi dalam bentuk apapun. Semua orang tetap harus saling menhargai perannya masing-masing. Karena perbedaan peran tersebut merupakan satu kepaduran yang tidak boleh diganggu.

Persoalannya, bisakah kita membangun satu sistem kehidupan yang "mutamaddin"40, sebuah tatanan kehidupan yang saling menghargai, mengormati, sadar hukum, berkeadilan, tanpa diskriminasi dan penuh dengan nuansa persatuan dan persaudaraan. Tidak ada yang merendahkan orang lain

\footnotetext{
${ }^{39}$ Lebih jauh telaah pada Hamdani, M.Ag., Masyarakat Patriarkhi..., 247.

40 Istilah ini diungkapkan KH. Sa'id Aqil Siradj, dalam ceramah agama pada Harlah ke 59 PP. Nurul Jadid Paiton Probolinggo. Menurut beliau, tatatanan kehiudpan yang "mutamaddin", justru tidak terdapat dalam negara yang berpenduduk muslim ataupun negara muslim sekalipun. Justru, kehidupan yang "mutamaddin" terjadi di sejumlahdaratan eropa. Sementara tatanan kehidupan umat islam sendiri, hanya ideologi; syariat dan aqidah yang mutamamddin. Sementara kondisi sosialanya, politik, ekonomi, masih terjebak pada pusaran "jahiliyyah". Masih suka bentrok, suka menodai nilai-nilai agama, suka menipu, dan sarat tindakan diskriminasi. Dikutip dari seri dokumentasi ceramah keagamaan, Harlah ke 59 PP. Nurul Jadid Paiton Probolinggo, disk ke-2, menit ke 11.15.
} 
berdasarkan jenis kelamin, perbedaan pekerjaan, suku, bangsa, kekayaan, dan lain sebagainya.

Sederhananya, konsep Feminisme kedepan mesti diarahkan pada upaya menumbuhkan kesadaran bahwa status apapun yang dimiliki kaum perempuan, sebagai ibu rumah tangga atau wanita karir sekalipun, mereka tetap harus dihormati. Dan itu adalah tugas kita, sebagai generasi kehidupan ini untuk terus "berperang" melawan ketidak adilan dalam bentuk apa pun. 


\section{DAFTAR PUSTAKA}

Al-Qr'an dan Terjemahannya, DEPAG RI.

Ahmad, Zubaer, M.Ag., (ed.), 2002, Membangun Kultur Ramah Perempuan, Jakarta: Restu Ilahi.

Al-Hasyimi, Ali, Muhammad, Dr. Tanpa Tahun, Jati Diri Wanita Muslimah (terj). Jakarta: Pustaka Al-Kautsar.

Ali Engginer, Asgar, Hak-Hak Perempuan dalam Islam, Farid Wajdi dan Cicik Farkha Assegaf (penj.), judul asli The Righ Of Women in Islam, Jogjakarta: Lembaga Studi dan Pengembangan Perempuan dan Anak.

Aripin, Jainal MA., Dr., 2010, (Ed.), Kajian Islam Multidisipliner (Jilid 3), Jakarta: LEMLIT UIN Syarif Hidayatullah.

Hamdani, M.Ag., 2004, Masyarakat Patriarkhi dan Perubahan Keluarga Muslim. Jakarta: Restu Ilahi.

Husain al-Hakim, Ali., dkk., 2005, Membela Perempuan Menakar Feminisme dengan Nalar Agama, Jakarta: Al-Huda.

Mesra, Alimin, M.Ag., 2006, Peran Perempuan dalam Keluaga; Kepemimpinan, Domestikasi, dan Peran Ganda, Jakarta: Restu Ilahi.

Mesra, Alimin., M.Ag., (Ed.), 2004, Membangun Kultur Ranah Perempuan; Reinterpretasi dan Aktualisisa, Jakarta: Restu Ilahi.

Muhammad, Husein, KH, 2007, Islam Agama Ramah Peremuan; Pembelaan Kiai Pesantren, Yogyakarta: LkiS.

Muhsin, Aminah Wadud, Qur'an Menurut Perempuan; Meluruskan Bias Gender dalam Tradisi Tafsir, Abdullah Ali, (Penj), Judul asli Qur'an an Women; Rereading The Secret Text From a Women's Prepective, Jakarta: PT Serambi Ilmu Semesta.

Muslihati, Siti, 2004, Feminisme dan Pembedayaan Perempuan dalam Timbangan Islam, Jakarta: Gema Insani Press.

Mustaqim, Abdul., MA., 2002, Tafsir Feminis Versus Tafsir Patriarkhi: Telaah Kritis Penafsiran Dekontruktif Riffat Hasan, Yogyakarta: LkiS.

Quraisyi, Shihab, M, 1995, Wawasan Al-Qur'an, Bandung: Mizan. 
Raqib, Moh, 2003, Pendidikan Perempuan, Yogyakarta: Gema Media.

Soekanto, Soerjono, 1998, Sosiologi Penyimpangan, Jakarta: Rajawali.

Suhaidi, Muhammad., RB., 2007, Dekontruksi Tafsir Gender Al-Qur'an; Telaah Kritis Atas Tafsir Feminin Aminah Wadud Muhsin dan Ashgar Ali Enggine, Sumenep. STIKA Press.

Warits, Abd., 2009, Nilai-Nilai Pendidikan Pemberdayaan Perempuan dalam Gerakan Feminis Islam, Sumenep: STIKA Press. 